\title{
Foreign Direct Investment and Government Policy in Central and Eastern Europe
}

\author{
Meyer, Klaus E.; Jensen, Camilla
}

Document Version

Final published version

Publication date:

2004

License

CC BY-NC-ND

Citation for published version (APA):

Meyer, K. E., \& Jensen, C. (2004). Foreign Direct Investment and Government Policy in Central and Eastern Europe.

Link to publication in CBS Research Portal

\footnotetext{
General rights

Copyright and moral rights for the publications made accessible in the public portal are retained by the authors and/or other copyright owners and it is a condition of accessing publications that users recognise and abide by the legal requirements associated with these rights.

Take down policy

If you believe that this document breaches copyright please contact us (research.lib@cbs.dk) providing details, and we will remove access to the work immediately and investigate your claim.
}

Download date: 26. Apr. 2023 


\title{
Foreign Direct Investment and Government Policy \\ in Central and Eastern Europe
}

\author{
Klaus E Meyer \\ km.cees@cbs.dk
}

and

Camilla Jensen

cj.cees@cbs.dk,

\section{Copenhagen Business School \\ Center for East European Studies, \\ Copenhagen Business School, \\ Howitzvej 60, 2000 Frederiksberg, \\ Denmark. Tel. (+45) 38153033 , \\ Fax (+45) 38152500. \\ http://www.cbs.dk/centres/cees/}

January, 2004

Acknowledgements: We thank Robert Grosse and participants of the conference on International Business and Government Relations in the $21^{\text {st }}$ Century in Phoenix Arizona for their comments on an early draft of this paper. We thank Thunderbird AGSIM for sponsoring the event.

Note: this paper is a draft for the book on "International Business and Government Relations in the $\mathbf{2 1}^{\text {st }}$ Century", Festschrift in Honor of Jack Behrmann, edited by Robert Grosse. Other contributors are: Jean Boddewyn, Joohn Dunning, Lee Preston, John Stopford, Thomas Brewer, Dong-Song Cho, Stephen Kobrin, Ravia Ramamurti, Stefan H. Robock, Dennis Rondinelli, Louis T. Wells, Paul Streeten, Lorraine Eden with Stephanie Lenway and Doug Shuler, Robert Grosse, Alan Rugman, Yadong Luo, and Alvint G. Wint. 


\title{
Foreign Direct Investment and Government Policy \\ in Central and Eastern Europe
}

\begin{abstract}
The 1990s have been a period of extraordinary politics in Central and Eastern Europe (CEE). This chapter discusses how the transition from state to market has created bureaucratic barriers to entry, but also windows of opportunity for foreign direct investment (FDI). The high costs and high investment risks associated with FDI in CEE are a reflection the institutional development. Thus, inflows of FDI have been largest in those countries that made most progress in establishing a market-oriented institutional framework.

After outlining trends of institutional change and their impact on FDI, this chapter discusses how aspects of the institutional framework and FDI policy affect diverse types of investment projects. Acquisition and Greenfield investors are concerned with different aspects of government policy: privatization and regulatory policies for acquirers and investment incentives, regional policy and special economic zones for Greenfield investors. The shifting policy priorities have thus changed the types of projects undertaken by foreign investors in the region.
\end{abstract}

\section{Introduction}

Relationships between MNE and governments in Central and Eastern Europe (CEE) have been shaped by the region's struggle to shed legacies of central planning, and create prosperous market economies. This context has created special challenges for both MNE and local governments to establish relations with each other, understand each others needs, and to engage in mutually beneficial negotiations.

Due to path dependency of institutions, extraordinary policies during this period and the inheritance from the previous regime shape the future institutional frameworks (North 1990, Stark 1992). Policy decisions during the period of radical change around 1990, such as methods of privatization, had a long-lasting effect on institutions, but also on the distribution of wealth and power. In many countries, the institutional vacuum and weak legal framework in the early 1990s permitted a large extent of opportunistic behavior, rent shifting, bribery and corruption; and in some countries, vested interests have inhibited the pace of reform (Stiglitz 1999, EBRD 
1999). Consequently, the process of building institutions in transition economies has taken more time than most reform scenarios envisaged in 1990.

The time of extraordinary politics and the pace of reform depend on each country's so-called market memory (Wolf and Havrylyshyn, 2002). Some countries were considered among the developed economies prior to World War II while others have gone directly from a feudal or early capitalist system to a socialist system. Moreover, the distinct cultural and systemic inheritances influence informal institutions such as norms and values in these countries. Consequently, Eastern Europe may develop distinctive forms of capitalism.

In this environment, government policy and changes in the institutional framework are of pivotal concern to foreign investors (Meyer 2001b). The transition has created specific policy-induced entry barriers, but also windows of opportunity for investors that established good relations or negotiated successfully with host governments. During radical institutional change, businesses cannot base their investment decisions on present institutions, as they are often transient and in some cases even inconsistent. Thus strategic flexibility and the ability to adapt to volatile rules and regulations can become crucial competitive advantages.

Recent research in both economics and business strategy has, in part through the analysis of transition economies, recognized the importance of institutions for business development and thus economic growth (Djankov 2003, Murrell 2003, Meyer and Peng 2003). The international business literature has long recognized the importance of government policy for the volume of FDI inflow and the strategies pursued by foreign investors. Institutional variables such as intellectual property rights protection (e.g. Oxley 1999) or political risk (e.g. Henisz 2000) have been incorporated in the study of foreign investment strategies, notably entry mode choice. However, the interaction between national economic institutions and enterprise level organizational strategies are still under-researched (Mudambi and Navarra 2002). This is particular relevant for transition economies because the underlying economic mechanisms are typically underdeveloped.

Foreign investors are firstly concerned how governments drive the general process of creating institutions for the market economy and lowering barriers to entry. However, multinational enterprises (MNE) entering a country by acquisition of a local firm interact with local authorities in different ways than Greenfield investors. Investors by acquisition are concerned with privatization policies and with the 
regulations of markets for corporate equity (Meyer, 2002). They often face bilateral negotiations, or multiple potential investors bidding for the same asset. Greenfield investors in contrast can often choose between many alternative sites for investment. They would thus have stronger bargaining positions vis-à-vis central or local authorities eager to attract FDI (Meyer and Nguyen, 2003, Jensen and Mallya, 2003).

This chapter is structured as follows. In the next section, we place the policy environment in $\mathrm{CEE}$ in a comparative context, before reviewing the impact of institutional development and government policy on foreign investment in Section 3. Section 4 and 5 focus on policy issues of concern to different types of investors depending on FDI entry-mode: acquisition vs. Greenfield. We conclude with an outlook on EU Enlargement, and point to the need for further research on the effect of policies on alternative types of FDI. We support our arguments with data on the policies adopted in the region, and with case studies to enhance the understanding of the relevance of the issues at firm level. 


\section{A comparative perspective}

Despite their distinct heritage, the countries of CEE appear to be converging toward development paths of other emerging economies at similar levels of income and development. According to the investment development path (IDP), government policies are in part predetermined by the country's level of development (Dunning, 1993; Dunning and Narula, 2000). The IDP stipulates a macroeconomic relationship between FDI, governments and development. Countries advance through the stages of development following five typical stages, yet their path is moderated by their policies towards international businesses.

The IDP proposes an endogenous relationship between the net-outward investment position (NOI per capita) of a country and its level of development proxied by GDP per capita. Transition economies are at different stages of this process. Bulgaria, Romania and the CIS (Commonwealth of Independent States) countries for which we have data (Ukraine, Belarus, Moldova and Russia) are at Stage 1 or Stage 2 of their development process (Table 1). Their location advantages, inclusive government policies and the sophistication of market-oriented institutions do not suffice to attract major inflows of FDI, while they have little if any outward FDI. An outlier is Russia, which received considerable FDI in its oil and gas sector, while Russian MNEs in this sector start investing abroad (Andreff, 2003). Yet relative to the size of the country, both inward and outward FDI in Russia remain small.

\section{INSERT TABLE 1 HERE}

The Central European countries have reached a mature phase of stage 2, as they continue to receive large amounts of inward FDI. Outward FDI started, but primarily in form of 'indirect' FDI by affiliates of MNE, for instance Hungarian affiliates of western MNEs undertaking investment in Romania or Ukraine (Andreff 2003). The Baltic Countries fall between the two major groups of countries, with Estonia belonging to a later phase of the Stage 2, while Latvia and Lithuania are still at early phases of stage 2. Slovenia falls in a category of its' own, reaching Stage 3 on the IDP with outward FDI taking off (see also Svetlicic and Bellak 2001).

The IDP literature suggests that countries start to liberalize their trade and FDI regimes as they advance in their stage of development (Dunning, 1993, Dunning and Narula, 2000). In other words, policy choices are to some extent endogenous to the 
IDP and hence the development process. Policies are typically import substituting and inward-looking at Stage 1 and Stage 2, when FDI inflows are moderate. Policies start to become more open and oriented towards attracting and incorporating FDI into the development process as countries approach Stage 3. Investment incentives geared toward foreign investors may be adopted at this stage. At stages 4 and 5, policies towards outward investments may take on importance.

The EBRD's external liberalization index provides an indicator of the extent of liberal and non-interventionist investment regimes in terms of national rules and legislations. Table 1 shows the level of external liberalization (foreign trade and exchange) in CEE countries on a scale from 1 (socialist system features e.g. foreign trade is controlled by the state and the current account is not liberalized) to $4+$ (standard for the most advanced industrial economies). These figures, albeit only a weak proxy for foreign investment legislation, indicate that liberal and outward oriented trade regimes are the rule rather than an exception among the former socialist countries, earning them the highest score in the EBRD assessment: $4+$. Only Belarus, Russia and Ukraine remain relatively unreformed or inward looking.

\section{INSERT TABLE 2 HERE}

A more detailed picture is provided by particular rules and legislations related to FDI (Table 2): free establishment, equal treatment, foreigners ability to purchase land, non-selectivity, access to privatization and repatriation of profits. The rules and laws of the investment regimes in CEE largely confirm the evidence of the EBRD indices. Most countries offer highly liberalized regimes and often are ahead with legislative reforms relative to their level of development. Again the CIS countries stand out as the most inward looking and unreformed regimes with respect to foreign investment laws. However, this picture may still be too optimistic with respect ot CIS in view to the actual investment barriers experienced by investors (see below).

Free establishment and profit repatriation are the norm across the region. Purchase of land by foreign investors is feasible in most countries, except Bulgaria, Belarus and Ukraine; while non-selectivity of the regulatory regime is still a concern in Russia and Ukraine. Other countries, like Slovenia, chose privatization methods that transferred ownership to domestic new owners and did not offer direct opportunities for foreign investors. However, in the late 1990s, opportunities for 
greenfield FDI and acquisitions from private owners increased, such that the privatization methods become less important for the volume of FDI attracted by any country (Bevan et al. 2004). New opportunities may emerge for acquisitions as insider-privatised firms in CIS may at some point in time need to raise capital, and thus seek foreign investors.

Survey-based research, such as carried out by the Confederation of Danish Industries (2003), demonstrates various barriers to investment: non-tariff barriers, red tape, the quality and applicability of laws and corruption. Based on in-depth interviews conducted with 45 Danish investors in Eastern Europe in the period 20022003, the study shows an increasing gap of barriers to entry in the Western and Eastern parts of the region. Barriers are far higher in the CIS countries. For example, the 19 licenses necessary to operate a business in Russia is among the largest in the world, whereas in Poland the number is 11 and in Denmark only 3. A similar example is corruption with Denmark being the $2^{\text {nd }}$ least corrupt country in the world, Poland coming on rank 45 and Russia at the bottom of the list in the $71^{\text {st }}$ place.

Transition began from relatively similar starting points; however, the paths of institutional development vary considerably. Differences arise from both inherited features of the institutional framework and the institutional reform of the 1990s. Government policy has played an important role in shaping the evolution of new institutions regulating FDI.

\section{Institutional Development and International Business in CEE}

The process of institutional development and divergence has arguably been the most important aspect of government policy affecting FDI in CEE. Economic institutions establish the rules and regulations for domestic economic actors as well as foreign investors. Institutions cover both formal institutions such as laws and regulations and informal institutions such as business practices and customs (North 1990).

For businesses operating in $\mathrm{CEE}$, institutions are much more than background conditions. Eastern Europe has gone through a process of fundamental institutional change under pressure of both internal and external political, economic and social changes. Yet the remaining inconsistencies of institutions increase transaction costs, especially for new business relationships, and thus inhibit many potential business relations, in particular those of complex or long-term nature. The resulting coordination failure has been a major cause of the deep recession of the early 1990's 
(Swaan 1997). Yet it also affects international businesses with the transition economies. Western MNEs lack information on their partners; and they have to confront unclear regulatory frameworks, inexperienced bureaucracy and the weak enforcement of property rights (Meyer, 2001a, Bevan et al. 2004).

The weaknesses of market institutions, and constraints on internalizing transactions, led to the widespread use of alternative, intermediate mechanisms of exchange through informal networks in CEE (Stark 1996), and even more in Russia (Puffer et al. 2000). Moreover, privatization created new forms of private ownership, including insider-owners and dispersed shareholders without effective stock market governance. Some of the largest firms in the region are subject to weak governance while enjoying close contacts to government and, in some CIS countries, considerable barriers to entry. Yet other firms have progressed far in shedding these legacies of the $20^{\text {th }}$ century. This diversity of governance mechanisms and of ownership patterns in the region may persist for many years.

Foreign entrants have to accommodate local institutions when designing an entry strategy. At an aggregate level, the stage of development of institutions is crucial to attract FDI, by reducing the transactions costs of setting up a local operation. Empirical research about the impact of host country institutions on the volume of FDI indicates the general impact of the institutional, social and legal framework. For example, Brenton et al. (1999) show an economic freedom index to be positively related to FDI flows in CEE.

Moreover, institutional variables influence specific strategic decisions such as the control, timing and location of foreign operations. Formal rules establish the permissible range of entry modes, for instance, with respect to equity ownership, and set the stage for possible bargaining between investors and authorities. Both formal institutions, such as the legal framework, and informal institutions, such as managerial networking, shape transaction costs in CEE, and consequently foreign investors' preferred mode of entry (Meyer 2001a).

Institutions and policy are particularly important when it comes to foreign investment by acquisition. In CEE, the institutions surrounding privatization set the context for foreign acquisition, as privatization policies and the policies affecting privatized firms have a direct bearing on the post-acquisition strategies (Meyer 2002) and performance (Uhlenbruck and DeCastro, 1998, 2000). We elaborate on these implications in section 4 . 
Bevan et al. (2004) investigate the impact of institutional development on FDI in transition economies and identify key factors by disaggregating subsets of institutional development. The results suggest that several institutional changes have particularly enhanced FDI receipts to transition economies:

- Development of private-owned businesses in place of state-owned firms;

- Development of the banking sector; but not necessarily the non-banking financial sector;

- Liberalization of foreign exchange and trade; but not necessarily of domestic markets and prices.

- Development of legal institutions; but not necessarily competition policy.

Contrary to their expectations, Bevan et al. (2004) find that domestic price liberalization and the development of competition policy do not appear to be significant in motivating FDI. This may reflect that the possibility of earning monopoly rents attracts foreign investors, yet often without benefiting local customers in the host economy. Thus, policy makers also have to be aware that what is good for domestic economic development does not necessarily attract more foreign investors, though possibly different ones. For example, competition policy eases entry, but it makes it less attractive to acquire an incumbent monopolist. Governments privatizing telecommunications often face a trade-off, as liberalization would reduce prices for consumers, but also reduces receipts from selling the incumbent state-owned service provider.

Competition is regarded as at least as important as privatization for enterprises to improve their efficiency - a result fully consistent with empirical research on privatization in the West (e.g. Vickers and Yarrow 1991). Yet while many major Western privatizations are industries with natural monopolies that require complex regulation to create competition, most firms privatized in CEE in the 1990s enjoyed monopoly powers courtesy of past or present government policy. After privatization it is essential that market forces are set free by removing administrative constraints. Firms in transition frequently face soft budget constraints and obtain protected market positions of various sorts. In Russia, a particular problem appears to be the lack of domestic entry, and thus contestable markets, in part due to protective intervention by regional authorities (Broadman 1999). 
The development of informal institutions may co-evolve with the establishment of formal institutions (North 1990). This makes it difficult to empirically show the additional impact of informal institutions. Bevan et al. (2004) find one result that can be explained by discrepancies between the development of formal and informal institutions. A Russia dummy variable, while negative and significant under most model specifications loses value when combined with legal effectiveness. The lack of effective law enforcement may therefore help to explain the poor FDI performance of Russia. Thus, investors are more concerned about formal institutions than about informal ones, unless informal institutions show highly unusual features.

In conclusion, government policy has been pivotal in creating new legal frameworks in transition economies, and indirectly influenced the social change that led to more gradual changes in informal institutions. Foreign investors have been affected by this institutional evolution while at the same time influencing institutional development. However, the research on which institutions are most critical for economic development, or for attracting FDI, does not yet allow conclusive answers. Below, we suggest that it may be more appropriate to disaggregate FDI by project characteristics to better understand the link between government policy and FDI inflows.

\section{BOX 1: OVERCOMING BARRIERS IN RUSSIA - THE DANDY WAY}

Despite reports of severe entry barriers in Russia there are also many examples of investors that have successfully overcome them and turned initial barriers into first-mover advantages. The Dandy case (a Danish chewing gum manufacturer acquired by Cadbury Schweppes in 2002) demonstrates this well. The company itself ascribes a great part of its success to the devotion of endless working hours towards establishing strong networks in Russia. This was done at all levels of the company-country hierarchy from the national to the regional and local levels. The CEO of Dandy spent initially months on establishing relations with Russian politicians at the highest level through private meetings, attending trade fairs and foreign investor promotions. Subsequently Dandy's expatriate local management team turned its attention to the regional level whilst negotiating a special incentive package and analyzing the success of other companies having located in the Novogorod region. Having opened the factory focus turned to local administrators and not least to the extended community of the factory's workers through sponsorships, the media, arranging parties and participation in charities.

Source: Hansted (2003); and interview with former CEO of Dandy Russia Carsten Bennike. 


\section{Acquisition entry, and the privatization processes}

At the onset of transition in 1989, state-enterprises dominated CEE economies, and the legal framework lacked provisions for the operation of firms in private ownership, let alone foreign ownership. This changed gradually, yet the institutional legacies induced many investors to partner with state enterprises. Joint ventures and acquisitions in the early to mid 1990's were generally related to the privatization process as foreign investors cooperated with, or took over state-owned firms. Especially large FDI projects were implemented by acquiring equity stakes in stateowned enterprises. Privatization thus offered unique opportunities for acquiring potentially lucrative assets at low prices.

Yet early acquisitions also carried special risks: the valuation of former state enterprises in a rapidly changing environment was subject to high uncertainties, and the turn around of the acquired business required major post-acquisition investments (Meyer and Estrin 2001). The failure rate of acquisitions is high, even within and between mature market economies. Yet, managing an acquisition is even more daunting in transition economies where acquirers operate in an unstable institutional contexts, and may be subject to governmental interference at all times.

The acquisition and the subsequent restructuring of former state-owned enterprises necessitate intensive interaction between the investor and government authorities, primarily the privatization agency. Moreover, the process typically involves many stakeholders in addition to the government. Groups such as employees of the firm, the management, local authorities, national unions, and media often take an active interest in privatization (AntalMokos 1998, Meyer 2002). Moreover, governments rarely act as homogeneous units, but different agencies and politicians like a local town major - pursue their own objectives. Managing the complex network of relationships is crucial for the success of the acquisition process (Figure 2).

\section{INSERT FIGURE 2 HERE}

Local stakeholders have diverse objectives, which may not always be compatible with those of profit-oriented investors. In addition, local governments, management and workers' councils with de jure or de facto influence on the negotiations complicate negotiation processes (Antal-Mokos 1998): 
- Governments not only maximize their financial revenues, but also pursue broader social objectives. Consequently, privatization negotiations generally involve wider issues such as investment plans and employment guarantees.

- $\quad$ Formally, potential buyers negotiate with the privatization agency. Yet a large number of agents inside and outside the firm try to influence the agency through formal or informal channels. This could degenerate into internal 'politicking', where agents pursue individual goals to the detriment of the organization and potential foreign partners.

- Frequently, managers and/or employees have attained considerable influence, especially in Poland and in many CIS countries.

The involvement of multiple stakeholder groups often prolongs the negotiation process. As time passes, the competitive situation changes due to events both within the target firm and in its environment, as management may be unable to pursue strategic leadership while future ownership remains uncertain. Thus, the market position may erode, and tangible and intangible assets may deteriorate as insiders extract assets, key people leave, or the organization fails to invest. Such deterioration would diminish the firm's prospects after privatization.

Yet, the governmental influence does not end with the formal privatization. Influences may be retained both direct, based on equity stakes of a state entity, or indirect. Political agents set regulatory policy, and they may exert moral suasion and political pressure in addition to interference based on specifically agreed terms in the privatization contract. State-owned enterprises often require deep organizational and strategic restructuring to be integrated in the investor's global organization. This creates major managerial challenges for acquiring firms as the process and its political context are more complex that for conventional acquisitions (Meyer 2002). MNE would normally prefer to design and implement such strategies without outside interference to be able to focus on economic objectives.

Governmental agencies other than the privatization agency can assert influence via formal institutions. Industrial regulation and competition policy have a particularly profound influence on market structure and, therefore, on postprivatization performance (Uhlenbruck and DeCastro 1998). Privatization-related acquisitions from the late 1990's onward have been primarily in sectors that require 
substantive governmental regulation, such as telecommunications, banking and utilities. In these industries, the regulatory frame is key to privatization negotiations as the privatized firm may hold a monopoly position. Vigorous industry liberalization and competition policy would not be in the interest of a foreign investor that took over an incumbent firm.

Governmental influence is most explicit where the state retains a minority share. Many acquisitions in the privatization process occurred in a staggered pattern, and were thus registered as JV although from the beginning the investor attained management control and envisaged the acquisition of full ownership. Such an arrangement permits acquisitions in a particular institutional context, and has little in common with conventional joint ventures. A temporary minority stake of a government may offer advantages to both partners. The government obtains some control over the firm's restructuring, and thus externalities created for the local economy, while capitalizing on the probable appreciation of the share value as the transition economy becomes less uncertain. Governments may also be reluctant to transfer control over firms deemed strategic, or trading with governmental institutions (Wright et al. 1993).

Investors normally aim for full control of acquired businesses not only to reduce transaction costs but also to enforce faster turnaround. In this respect, foreign investors may dislike the possible government interference in strategic decisions, but would appreciate the risk sharing, the lower amount of capital to be raised at the outset, and the access to local institutions and networks. If the acquirer attains management control, the influence of the co-owner on operational management may be limited.

Furthermore, the interests of the regional or local authorities may become more aligned with those of the acquiring firm if they share the profits. This should reduce undue bureaucracy and regulatory interference, while providing access to important public and private networks. Such informal networks are vital for businesses in transition economies, especially in Russia (Puffer et al. 2000, Holden et al. 1998) and China (Peng \& Heath 1996).

Hence, minority government ownership can have contradictory effects. In mature market economies, firms in mixed ownership may generate lower profits because governments aim at social rather than financial returns. Yet this does not translate to transition economies, where for example Tian (2003) finds an inverse-U- 
shaped relationship between state-ownership stakes and corporate performance. Residual state ownership thus has both positive and negative effects.

Even without quity stakes, the authorities may retain rights in the privatization process. The privatization contract can create a principalagent type relationship between the government and the acquirer beyond the privatization (Stark 1992). Deal terms can, for instance, stipulate employment guarantees, investment commitment, partial local ownership, or that the management team be staffed with nationals. The enforcement of such contracts, which were widely used for instance by the East German Treuhandanstalt, is however problematic and may lead to ongoing negotiations.

Informal institutions may moderate the new owners' control over the acquired business. Public opinion and, in consequence, political agents, frequently take an interest in formerly state-owned firms. This may trigger governmental intervention if the new owner's actions are thought not to be in the country's best interest. In addition to social objectives, politicians and bureaucrats may pursue personal objectives and engage in various form of rent-seeking behavior. This may foster corruption, as seen in Russia. Foreign investors have to distinguish legitimate social concern from individual rent-seeking behavior.

Acquirers thus have to be aware of potential conflicts with political agents, and of the social consequences of their corporate activity. Where legal and regulatory frameworks are not yet fully developed, politician may feel called upon to interfere in former state-owned firms in case of social conflicts.

In conclusion, foreign investors entering $\mathrm{CEE}$ by privatization-acquisitions typically have to negotiate with multiple stakeholders in the firm, the government, and society. The relationship between government and the foreign investor extends beyond the time of formal take-over of the firm as acquirers pursue the often necessary deep restructuring of the acquired firm, while governments or political groupings are concerned with the social consequences of such restructuring processes.

MNEs aiming to enter a foreign country by acquiring a local firm thus are most concerned with the institutions governing markets for corporate control, which in CEE implies privatization policies, and policies vis-à-vis privatized enterprises. They are also concerned with a range of other policies, such as regulatory policies visà-vis market incumbents, and informal means of exerting political influence on business. 


\section{Greenfield entry, and the bargaining for subsidies}

Greenfield investors do in contrast not normally have to deal with privatisation agencies or the regulation of natural monopolies. Their investment rarely conflicts with existing power structures in bureaucracies or incumbent firms.

Greenfield investor's relationships with authorities are more likely aimed at realizing mutual benefits. Local governments welcome investors that promise employment opportunities, technology spillovers and taxable revenues. Their eagerness to attract FDI may translate in competition between different authorities offering investment incentives, and provides considerable bargaining power to some potential investors, notably those considering large projects and aiming to serve more than a local market.

Incentive schemes abound in CEE at the turn of the century. A variety of incentives are offered to potential investors, the most common being tax holidays. They are likely to converge to the EU rules ${ }^{1}$ as the CEE countries enter the EU, starting with the first wave in 2004. Many CEE countries will be allowed to offer incentives within the EU for some time either within the rules of the EU, or because of the transitory arrangements that are part of the accession process (The Commission, 2003). Hence, such schemes will continue to be important and may affect in particular location decisions of Greenfield investors offering large manufacturing projects. Moreover, the CEE countries entering the EU will have access to new resources through the structural funds, which may be used also for investment incentives. However, this may induce the new members to use more systematic and transparent rules and to abstain from anti-competitive or illicit practices.

Investors seeking to establish production facilities for global markets often face a wide choice of locations. To produce goods that are subject to low transportation costs and be distributed easily to worldwide markets, investors can search worldwide for an optimal site. Especially if they do not require specific local inputs, but offer substantial potential spillovers to the local environment, they can use

\footnotetext{
${ }^{1}$ Under EU rules, incentives may be used primarily for regional policy (including labour market and R\&D policies) under the EU structural funds. For example, only the relatively poor regions (with GDP below 75 percent of EU average at present) are allowed within the EU to use incentives as a way to attract new businesses to their location. But many regions in Eastern Europe will fall in this category
} 
their leverage to negotiate with local authorities to obtain favorable conditions. Local or national authorities may offer not only financial and fiscal incentives (i.e. tax exemptions), but promise investment in infrastructure development.

For investors, these incentives offer direct financial advantages and may even add to the strategic-assets of the company. For instance, policy may create the basis for dynamic economies of scale in locations through provisions of temporary incentives or protection from import competition as in the Central European car industry (Werner, 2003). On the other hand, recipients of subsidies put their reputation on the line, if for example they fail to balance government objectives connected to the incentive schemes and its own business objectives. Firms that participate in an incentive scheme, but subsequently do not live up its conditionality, can expect negative press reaction. This also holds true for firms that enter into a nontransparent deal with a government, which may make the public wonder what is kept secret. Incentive schemes are often linked to performance requirements, made attractive by a gift package of dollar bills. Failure to live up to the performance criteria may damage a firm's reputation and lead to complex legal issues and possible need to repay received subsidies.

\section{BOX 2: THE EMERGENCE OF A CAR INDUSTRY CLUSTER}

The car industry is the most prominent example of how Brownfield investment opportunities along with Greenfield investments into special economic zones in various locations in CEE, spiced up by incentives may corroborate to establish a geographical cluster of producers. Research shows how the car industry in Poland, Czech Republic and Hungary is located within a radius of only $200 \mathrm{~km}$. Hence agglomeration economies emerged thanks to a combined government strategy taking outset in the location of existing facilities. It has been enhanced by incentives and competition among neighbouring locations in different countries.

The symbiosis between government and international business in the car industry has created a critical mass in the industry. This policy opened opportunities for both acquisition and Greenfield FDI during a window of opportunity. It allowed investor to overcome the high barriers in the beginning of transition process and facilitated larger and more risky projects. The early entrants in turn created new windows of opportunity for later investors such as subsuppliers in the car industry. Investment barriers have come down faster than in other industries because of a fit between government and investor objectives. The Czech authorities recognized early that they would only be able to overcome the technological gap to the world car industry by attracting foreign investor, and inducing them to, in particular VW, to locate substantive value adding activity here. Ten years later, this has become the basis for one of CEEs strongest industry clusters.

Sources: Werner (2003), Meyer (2000). 
Most CEE countries use SEZs as part of their FDI policies. They come in two formats:

- Free economic zones, where investors are exempted from paying customs duties or other taxes, possibly conditional on certain performance requirements related to employment or exports, and

- Industrial parks or 'technology parks', where the aim is to build clusters of industry that will generate spillovers to the local economy.

\section{INSERT TABLE 3 HERE}

Table 3 gives an overview of incentive schemes in Eastern Europe, based on a study by Dresdner Bank (2003), complemented with qualitative information obtained from the homepages of national investment agencies. ${ }^{2}$ Almost all countries in CEE offer some type of incentive scheme. The only exceptions are Estonia and Lithuania, which however offer some of the lowest corporate tax rates in the world. This shows how CEE countries seek to market their regions in the investor community in terms of cost advantages.

On a less regular basis, several countries also use incentives in relation to special economic zones (SEZs). These policies primarily focus on the provision of infrastructure or pools of labour with a specific skill structure. Most countries combine both types of incentives. However, in Table 3 also the usage of regular incentive schemes has been put in parentheses in those cases where a case-by-case approach has been the overwhelming one, as in Latvia and Lithuania.

Especially in the countries furthest to the east, incentives are tied to SEZ, e.g. in Romania, Bulgaria and Poland and in CIS countries. The main performance requirements relate to job creation, and in some countries such as Hungary and Czech Republic also to the amount of capital invested. In practice, the requirements may not differ much, as all countries aim to attract large investors with manufacturing projects to the least developed regions, either directly by setting job creation objectives or

\footnotetext{
${ }^{2}$ For example, in the case of Russia, the information provided by Dresdner Bank is very scant. Visiting the official investment site of Russia (www.inves.ru) reveals that Russia has adopted a case-by-case approach as the rules under which incentives may be provided are expressed rather vaguely.
} 
indirectly by creating SEZs in the least developed regions with high unemployment. Hence performance requirements are overall not a major constraint for business, except perhaps in some of the countries applying a case-by-case approach where part of the package negotiated may include strict local content requirements. If the company subsequently divests prior to the termination of the incentive contract it must be prepared to pay back the value of incentives which may amount to as much as $50 \%$ of the original investment (Jensen and Mallya, 2002). Whether such contracts are enforceable is another matter.

Some countries offer incentives at several levels of government. In the Polish system, probably the most decentralised, incentives can only be negotiated with the local governors of the SEZs. Such decentralization offers opportunities for entrepreneurial local authorities to create a more investor friendly environment where central reforms are sluggish or inconsistent, as observed in Vietnam (Meyer and Nguyen 2003).

In other cases (Czech Republic and Ukraine), the additional layers of government may pose both a blessing and a curse to the managers at the negotiation table. Investors may be able to negotiate higher subsidies if multiple sources of funds are available. At the same time, the danger of multiple requests for special favours increases, such that the net gain from obtaining incentives can be difficult to foresee, and costs of negotiating may exceed received benefits. Hence in countries where the incentive-negotiation environment is very complex (case-by-case approach, large size of informal economy and several layers of negotiation), such as Ukraine, competent legal counsellors may be a prerequisite to negotiating for incentives.

The provision of incentives related to trade, e.g. import protection in combination with incentives can be an important strategic aspect to investors not only in the CIS, but in all CEE countries (Werner, 2003). Hence Table 3 gives only indicative information about the prevailing nature of incentive schemes, while a caseby-case approach has been adopted all over the region vis-à-vis very large investors.

These incentive schemes can broadly be divided into two groups: the transparent and publicly visible schemes and the less transparent schemes negotiated between top government and (typically very large) multinational investors on an individual case-by-case basis (UNCTAD, 2003). Transparent incentive schemes available to all investors meet certain criteria attract mainly medium and large investors with cost oriented motives. The non-transparent incentives are often 
associated with major multinational firms building government relations, which then can be viewed as a strategic asset. However, to our knowledge there exists very little research on how multinationals can build and exploit government relations in CEE, in part probably because of the non-transparent aspects of these deals.

In the countries that are not (yet) acceding to the EU, the case-by-case approach to investors might lead to more corrupt behaviour by government representatives (UNCTAD, 2003). Since these countries are beyond the immediate reach of institutional spillovers from the EU, and have a high estimated share of informal economy (Johnson and Kaufmann, 2001), they may be more prone to adopt non-transparent incentive schemes.

In conclusion, investment incentive schemes are widespread in CEE, and often relate to the creation of SEZ. They aim at attracting capital and employment to particular regions, and focus on Greenfield manufacturing projects. Yet, do these schemes have had any visible impact in terms of crowding-in FDI.

Most studies, even at the national or local level, suggest that incentive programs generally fail to crowd-in FDI (Morriset and Pirnia, 2000, Oman, 2000). In a panel analysis of the transition countries, Beyer (2002) finds that the announcement of incentive programs has among other factors little impact on their attraction of FDI. An earlier review of ax incentives in transition countries by Holland and Owens (1996) also concludes that incentives appear to play a marginal role in attracting investors. In a study of the Czech Incentive Scheme, Jensen and Mallya (2002) find based on survey data for 135 investors in manufacturing that at most the scheme succeeded in crowding-in total investments with 3-5\% per year. However, within the target group of Greenfield investors in manufacturing the marginal impact is somewhat greater at $10 \%$ per year.

The strongest impact of incentives schemes has been reported for in the car industry, in combination with a host of other location advantages (Werner, 2003) see also Box 2 above. This pattern may be replicated in other industries, if incentives help develop industrial clusters that might become regional hubs for production in the enlarged EU. However, the type of deal that the Czech government stroke with VW in the early 1990, which included for instance temporary infant industry tariff protection, would not be permissible under WTO rules, let alone EU membership.

The main effect of incentives offered on the rim of the EU appears to be to attract investments to one country under the nose of its neighbour, rather than raising 
overall investment in the region. This competition for FDI is intensifying before accession to the EU (UNCTAD, 2003). A similar battle for FDI rages among countries of the 'old' EU. With high unemployment, slow economic growth, and the relative insecurity about what Enlargement will bring in terms of geographical reorganisation of industries, governments resort to incentive schemes as leverage when negotiating with potential investors.

This empirical evidence suggests that investment incentives schemes have become more systematic (transparent) and marginally more important to the location decision of Greenfield investors in large manufacturing projects in CEE. However, these incentives have mainly influenced the marginal cost of locating in one CEE country rather than another. As Greenfield investments increase where privatization is completed, zones may become more important for investors' location strategy.

Incentives will continue to influence the location strategies of Greenfield investors after EU accession, since most of the CEE region will be eligible to use such incentive schemes in the foreseeable future. Moreover additional funds may be available when the EU programs are extended to accession countries. Countries with the administrative capabilities to manage incentives schemes such as the Czech Republic, Poland and Hungary may offer a major benefit to investors negotiating for incentives. But with rising income and wage levels in the EU accession countries, zones have to offer both incentives and attractive resource endowment, especially human capital, to attract investors.

\section{Conclusion}

The transition economies have gone through a rapid process of institutional development. During this period, extraordinary politics have created unique business opportunities for investors who could manage government-relations in a rapidly changing context.

With the EU Enlargement in 2004, the period of extraordinary politics is coming to a close. Yet this does not imply an end to proactive FDI policies; rather, future policies will be adapted to the overall legal EU framework. The policy agenda is shifting. While some windows of opportunity are closing others are opening up. Rather than privatization, the main policy questions of the near future are likely to center on regional policy within the EU frameworks and EU competition policy in an 
enlarged Union. New opportunities in the CIS countries depend on their progress with internal reforms and enterprise restructuring.

The relevant policy issues of concern to investors vary over time, and with the type of FDI. This feature should also apply in other regions, and we thus propose that policy researchers differentiate more clearly the impact of policy and institutions on different types of FDI, for instance by mode of entry between FDI by acquisition and Greenfield respectively. This chapter has shown that acquisitions in Eastern Europe have created complex relationship between government policy, business strategies and institutional development. Governments and multinational firms face difficult balancing acts to manage their interdependencies, and to secure mutual benefits. For Greenfield investments, the mutual benefits among the various stakeholders involved appear more obvious and conflict less with other objectives of economic policy.

For FDI by acquisition, key concerns relate to the bargaining with privatization and regulation authorities and the restructuring of formerly state-owned enterprises. However, foreign investors increasingly acquire private firms. This reduces the intensity of their interaction with the authorities, yet when buying a recently privatized firm, they may still face deep restructuring to shed the legacy of a firm once run as a socialist enterprise.

Foreign investors pursuing Greenfield entry have more degrees of freedom with respect to their intra-country location choices. This gives them high bargaining power vis-á-vis local municipalities, and the opportunity to take advantage of special incentives in SEZs and industrial parks. For local policy makers, this raises the challenging policy issue of whether they want to attract FDI by offering special incentives, which might benefit the specific location but come at the cost of overall social welfare. Empirical evidence suggests that incentive are only effective to certain types of FDI, i.e. large scale manufacturing Greenfield projects that do not depend on specific locational advantages. Incentive programs thus encourage only certain types of FDI. Policy makers would hope that these are projects with the largest spillovers.

However, a major explanatory factor for such policy is the relative bargaining positions of authorities and MNE. Governments aiming to attract foreign investors by selling a strong local firm, such as an incumbent telecom operator, have a valuable asset and thus often a strong bargaining position. It is less strong if they seek a partner for a loss-making firm in a declining industry such as steel. To attract Greenfield investors, countries offering distinct locational advantages such as an industrial 
cluster or human capital have stronger negotiation positions then those offering only financial incentives.

\section{References:}

Andreff, Wladimir (2003): 'The Newly emerging Transnational Corporations from Transition Economies - Comparison with Third World outward foreign direct investment', forthcoming in Transnational Corporations.

Antal-Mokos, Z. 1998. Privatisation, Politics, and Economic Performance in Hungary. Cambridge: Cambridge University Press.

Bevan, Alan A., Saul Estrin and Mark Schaffer (1999): Determinants of Enterprise Performance during Transition, Working Paper no. 99/03, Center for Economic Reform and Transformation, Heriot-Watt University, Edinburgh.

Bevan, A., S. Estrin and K. Meyer (2003): Foreign Investment Location and Institutional Development in Transition Economies, International Buiness Review, 13 (2004), no. 1, p. 43-64.

Beyer, J. (2002). 'Please invest in our country - how successful were the tax incentive for foreign investment in transition countries?', Communist and PostCommunist Studies, 35, pp 191-211.

Brenton, P., F. Di Mauro \& M. Lücke. 1999. Economic Integration and FDI: An Empirical Analysis of Foreign Investment in the EU and in Central and Eastern Europe. Empirica, 26(2): 95-121.

Clark, E. \& A. Soulsby. 1995. Transforming former state enterprises in the Czech Republic. Organization Studies 16: 215-242.

The Commission (2003): 'Report on the results of the negotiations on the accession of Cyprus, Malta, Hungary, Poland, the Slovak Republic, Latvia, Estonia, Lithuanad, the Czech Republic and Slovenia to the European Union', paper prepared by the Commission's departments, The Commission for the European Union, Brussels.

DI(2003): 'En slagkraftig og barrierefri Østersøregion? - Spræng murbrokkerne væk!', Confederation of Danish Industries, June 2003, Copenhagen.

Djankov, S., E. Glaeser, R. La Porta, F. Lopez-de-Silanes and A. Shleifer (2003): The new comparative economics, Journal of Comparatve Economics 31, p. 595619.

Dresdner Bank (2003): Investing in Central and Eastern Europe, July 2003, Dresdner Bank AG, Group Economics, Frankfurt am Main.

Dunning, J. 1993. Multinational enterprises and the global economy. Wokingham, UK: Addison-Wesley.

Dunnning, J. and R. Narula (1996): Foreign direct investment and governments, catalysts for economic restructuring, London: Routledge.

EBRD. 1999, 2001. Transition Report. London: European Bank for Reconstruction and Development.

Gomes-Casseres, B. 1991. Firm Ownership Preferences and Host Government Restrictions. An Integral Approach. Journal of International Business Studies, 21: 1-22.

Guisinger, S. et al. 1985. Investment Incentives and Performance Requirements, Patterns of International Trade, Production and Investment. New York: Praeger.

Hellman, Joel S., G. Jones, D. Kaufmann and M. Schankerman (2000): 'Measuring Governance, Corruption and State Capture - How Firms and Bureaucrats 
Shape the Business Environment in Transition Economies', WB Policy Research Working Paper, no. 2312, The World Bank, Washington.

Henisz, W. J. 2000. The Institutional Environment for Multinational Investment. Journal of Law, Economics and Organization, 16(2): 334-64.

Holden, N., C. Cooper and J. Carr (1998): Dealing with the New Russia: Management Cultures in Collision, Chichester et al.: Wiley.

Holland, David and Jeffrey Owens (1996). 'Taxation and Foreign Direct Investment: The Experience of the Economies in Transition', Bulletin for International Fiscal Documentation, 50 (2).

Jensen, C. and T.J.S. Mallya (2002): 'Are FDI incentive programs a good investment for the host country? - an empirical evaluation of the Czech National Incentive Scheme' revised CEES Working Paper, no. 2002-46, Centre for East European Studies, Copenhagen Business School.

Jensen, C. and T.J.S. Mallya (2003): 'Foreign direct investment and regional growth in transition economies - a comparative study of the Czech Republic and Poland', unpublished working paper.

Johnson, Simon and Daniel Kaufmann (2001): 'Institutions and the Underground Economy', in (eds. Havrylyshyn, O. and S.M. Nsouli) A Decade of Transition: Achievements and Challenges, The International Monetary Fund, Washington.

Meyer, K.E. 2000. International Production Networks and Enterprise Transformation in Central Europe, Comparative Economic Studies 42, p. 135-150.

Meyer, K.E. 2001a. Institutions, Transaction Costs and Entry Mode Choice. Journal of International Business Studies, 31(2): 257-67.

Meyer, K.E. 2001b. International Business Research on Transition Economies, in: T. Brewer and A. Rugman, eds: Oxford Handbook of International Business, Oxford: Oxford University Press, 2001.

Meyer, K. E. 2002. Management challenges in privatization acquisitions in transition economies. Journal of World Business, 37: 266-276.

Meyer, K.E. and S. Estrin (2001): Brownfield Entry in Emerging Markets, Journal of International Business Studies 31, no. 3, p. 575-584.

Meyer, K.E. and H.V. Nguyen (2003): Foreign Investor's Entry Strategy and Subnational Institutions in Vietnam, SMS Mini-conference, Hong Kong, December 2003.

Meyer, K.E. and M.W. Peng 2003. Identifying Leading Theories for research on Central and Eastern Europe: Transactions, Resources and Institutions, mimeo, Copenhagen Business School and Ohio State University.

Morisset, Jacques and Neda Pirnia (2000). 'How Tax Policy and Incentives Affect Foreign Direct Investment - A Review', Policy Research Working Paper, 2509, (Washington: The World Bank).

Mudambi, R. and R. Navarra 2002. Institutions and International Business: A Theoretical Overview, International Business Review 11, no. 6, p. 635-646.

Murrell, P. (2003): Firms facing new institutions: transactional governance in Romania, Journal of Comparatve Economics 31, p. 695-714.

North, D.C. 1990. Institutions, Institutional Change and Economic Development, Cambridge University Press.

Oman, Charles (2000). Policy competition for foreign direct investment - a study of competition among governments to attract FDI, (Paris: Development Center Studies, Organisation for Economic Co-operation and Development). 
Oxley, J.E. 1999. Institutional Environment and the Mechanisms of Governance: The Impact of Intellectual Property Protection on the Structure of Inter-Firm Alliances. Journal of Economic Behavior and Organization, 38(3): 283-310.

Peng, M. W., \& Heath, P. 1996. The growth of the firm in planned economies in transition: Institutions, organizations, and strategic choices. Academy of Management Review, 21 (2): 492-528.

Puffer, S., D. McCarthy, \& A. Naumov. 2000. The Russian capitalist experiment: From state-owned organizations to entrepreneurships. Cheltenham, UK: Edward Elgar.

Stark, D. (1992): Path Dependence and Privatization Strategies in East Central Europe, East European Politics and Society 6, p. 17-54.

Stark, D. 1996. Recombinant property in East European capitalism. American Journal of Sociology, 101: 993-1027.

Stiglitz, J. 1999. Whither Reform? Ten Years of Transition. Keynote address at the Annual Bank Conference on Development Economics, World Bank, Washington.

Svetlicic, M. and C. Bellak (2002): 'The Investment Development Path of Small Countries: Comparative Evaluation of Slovenia and Austria', paper prepared for the AIB 2002 Annual Meeting, in San Huan, Puerto Rico.

Swaan, W. 1997. Knowledge, transaction costs and the creation of markets in postsocialist economies, in: P.G. Hare \& J. Davis, eds: Transition to the Market Economy: 53-76. London: Routledge.

Tian, G. (2002): Corporate Governance in China, unpublished PhD Dissertation, London Business School.

Uhlenbruck, K. and J. de Castro (1998): Privatization from the Acquirer's Perspective: A Mergers and Acquisitions Model, Journal of Management Studies 35, p. 619-640.

Uhlenbruck, K. and J. de Castro (2000): Foreign Acquisitions in Central and Eastern Europe: Outcomes of Privatization in Transitional Economies, Academy of Management Journal,.

UNCTAD (2003): World Investment Directory - Volume VIII Central and Eastern Europe 2003, United Nations Conference on Trade and Development: New York and Geneva.

Vickers, J. \& G. Yarrow (1991): Economic Perspectives on Privatization, Journal of Economic Perspectives 5, no. 2, p. 111-132.

Werner, R. (2003): 'Location, Cheap Labor and Government Incentives: A Case Study of Automotive Investment in Central Europe Since 1989', Chazen Web Journal of International Business, Spring 2003 (www.gsp.columbia.edu/chazenjournal).

World Bank (2002): 'Far from Home: Do Foreign Investors Import Higher Standards of Governance in Transition Economies?', WB Discussion Paper, The World Bank, Washington.

Wright, M., S. Thompson and K. Robbie (1993): Finance and Control in Privatisation by Management Buy-out, Financial Accountability and Management 9, no. 2, p. $75-99$. 
Table 1: FDI and Institutional development, 2001

\begin{tabular}{|c|c|c|c|c|c|c|c|}
\hline Country & $\begin{array}{l}\text { FDI stock } \\
\text { per } \\
\text { capita, } \\
\text { US\$ }\end{array}$ & $\begin{array}{l}\text { NOI } \\
\text { per } \\
\text { capita, } \\
\text { US\$ }\end{array}$ & $\begin{array}{l}\text { EU } \\
\text { member- } \\
\text { ship }\end{array}$ & $\begin{array}{l}\text { External } \\
\text { liberali- } \\
\text { sation }\end{array}$ & $\begin{array}{l}\text { Privati- } \\
\text { zation } \\
\text { (large) }\end{array}$ & $\begin{array}{l}\text { Compe- } \\
\text { tition } \\
\text { policy }\end{array}$ & $\begin{array}{l}\text { Legal } \\
\text { effective- } \\
\text { ness }\end{array}$ \\
\hline \multicolumn{8}{|c|}{ Stage 1-2 countries } \\
\hline Albania & 240 & -215 & No & $4+$ & 3 & 1 & 2 \\
\hline Belarus & 140 & -135 & No & 2 & 1 & 2 & 3 \\
\hline Bulgaria & 490 & -475 & Cand. & $4+$ & $4-$ & $2+$ & $4-$ \\
\hline Latvia & 920 & -820 & In 2004 & $4+$ & 3 & $2+$ & 4 \\
\hline Lithuania & 725 & -710 & In 2004 & $4+$ & $3+$ & 3 & $4-$ \\
\hline Moldova & 140 & -140 & No & $4+$ & 3 & 2 & $4-$ \\
\hline Romania & 340 & -335 & Cand. & 4 & $3+$ & $2+$ & 4 \\
\hline Russia & 150 & -50 & No & 3- & $3+$ & $2+$ & $4-$ \\
\hline Ukraine & 95 & -90 & No & 3 & 3 & $2+$ & 3 \\
\hline \multicolumn{8}{|c|}{ Stage $2-3$ countries } \\
\hline Estonia & 2290 & -1980 & In 2004 & $4+$ & 4 & 3- & 4 \\
\hline $\begin{array}{l}\text { Czech } \\
\text { Republic }\end{array}$ & 2610 & -2525 & In 2004 & $4+$ & 4 & 3 & 3 \\
\hline Hungary & 2375 & -1935 & In 2004 & $4+$ & 4 & 3 & $4-$ \\
\hline Poland & 1100 & -1075 & In 2004 & $4+$ & $3+$ & 3 & 3 \\
\hline $\begin{array}{l}\text { Slovak } \\
\text { Republic }\end{array}$ & 1130 & -1060 & In 2004 & $4+$ & 4 & 3 & $3+$ \\
\hline \multicolumn{8}{|c|}{ Stage 3 country } \\
\hline Slovenia & 1415 & -1012 & In 2004 & $4+$ & 3 & $3-$ & 4 \\
\hline
\end{tabular}

Notes: column 4: Cand. = candidate country, membership forecasted for 2007. No = not member and membership not expected in the near future. Column 5 to 8: EBRD transition indicators, based on annual assessment by the Chief Economist's office of the EBRD, scale $1=$ 'socialist system feature' $4=$ 'standard and performance norms of advanced industrial economies'.

Sources: Figure 1 and EBRD (2002): Transition Report, European Bank for Reconstruction and Development, London. 

Figure 2: A Process Perspective on Privatization Acquisitions



Source: Meyer (2002). 

Table 2: Investment rules and legislation in individual CEE countries

\begin{tabular}{|c|c|c|c|c|c|c|c|}
\hline & & $\begin{array}{l}\text { Free } \\
\text { establishment }\end{array}$ & $\begin{array}{l}\text { Equal } \\
\text { treatment }\end{array}$ & $\begin{array}{l}\text { Purchase } \\
\text { of land }\end{array}$ & $\begin{array}{l}\begin{array}{l}\text { Non- } \\
\text { selectivity }\end{array} \\
\end{array}$ & $\begin{array}{l}\text { Access to } \\
\text { privatisation }\end{array}$ & $\begin{array}{l}\text { Profit } \\
\text { repatriation }\end{array}$ \\
\hline \multirow[t]{9}{*}{ Stage 1-2 } & Albania & $\mathrm{v}$ & $\mathrm{v}$ & (v) & (v) & $\mathrm{v}$ & $\mathrm{v}$ \\
\hline & Belarus & $\mathrm{v}$ & (v) & $(-)$ & $(-)$ & $(-)$ & $\mathrm{v}$ \\
\hline & Bulgaria & $\mathrm{v}$ & (v) & $(-)$ & (v) & (v) & $\mathrm{v}$ \\
\hline & Latvia & $\mathrm{v}$ & $\mathrm{v}$ & $\mathrm{v}$ & $\mathrm{v}$ & (v) & $\mathrm{v}$ \\
\hline & Lithuania & $\mathrm{v}$ & $\mathrm{v}$ & (v) & $\mathrm{v}$ & (v) & $\mathrm{v}$ \\
\hline & Moldova & $\mathrm{v}$ & $\mathrm{v}$ & $\mathrm{v}$ & (v) & (v) & $\mathrm{v}$ \\
\hline & Romania & $\mathrm{v}$ & $\mathrm{v}$ & $\mathrm{v}$ & (v) & $\mathrm{v}$ & $\mathrm{v}$ \\
\hline & Russia & $\mathrm{v}$ & (v) & (v) & - & $(-)$ & $\mathrm{v}$ \\
\hline & Ukraine & $\mathrm{v}$ & (v) & $(-)$ & - & $(\mathrm{v})$ & $\mathrm{v}$ \\
\hline \multirow[t]{5}{*}{ Stage 2-3 } & Estonia & $\mathrm{v}$ & $\mathrm{v}$ & $\mathrm{v}$ & $\mathrm{v}$ & $\mathrm{v}$ & $\mathrm{v}$ \\
\hline & Czech Rep. & $\mathrm{v}$ & $\mathrm{v}$ & $\mathrm{v}$ & (v) & (v) & $\mathrm{v}$ \\
\hline & Hungary & $\mathrm{v}$ & $\mathrm{v}$ & $\mathrm{v}$ & $\mathrm{v}$ & $\mathrm{v}$ & $\mathrm{v}$ \\
\hline & Poland & $\mathrm{v}$ & $\mathrm{v}$ & $\mathrm{v}$ & (v) & (v) & $\mathrm{v}$ \\
\hline & Slovak Rep. & $\mathrm{v}$ & $\mathrm{v}$ & $\mathrm{v}$ & (v) & $(\mathrm{v})$ & $\mathrm{v}$ \\
\hline Stage 3 & Slovenia & $\mathrm{v}$ & $\mathrm{v}$ & (v) & $\mathrm{v}$ & $(-)$ & $\mathrm{v}$ \\
\hline
\end{tabular}

Notes $\mathrm{v}=$ Fully applicable, (v)= Applicable with some exceptions, (-)=Not applicable with some exceptions, -=Not applicable

Source: UNCTAD (2003): World Investment Directory, published by the United Nations Conference on Trade and Development on the Internet (www.unctad.org). 

Table 3: Overview of regular incentive schemes offered in Eastern Europe

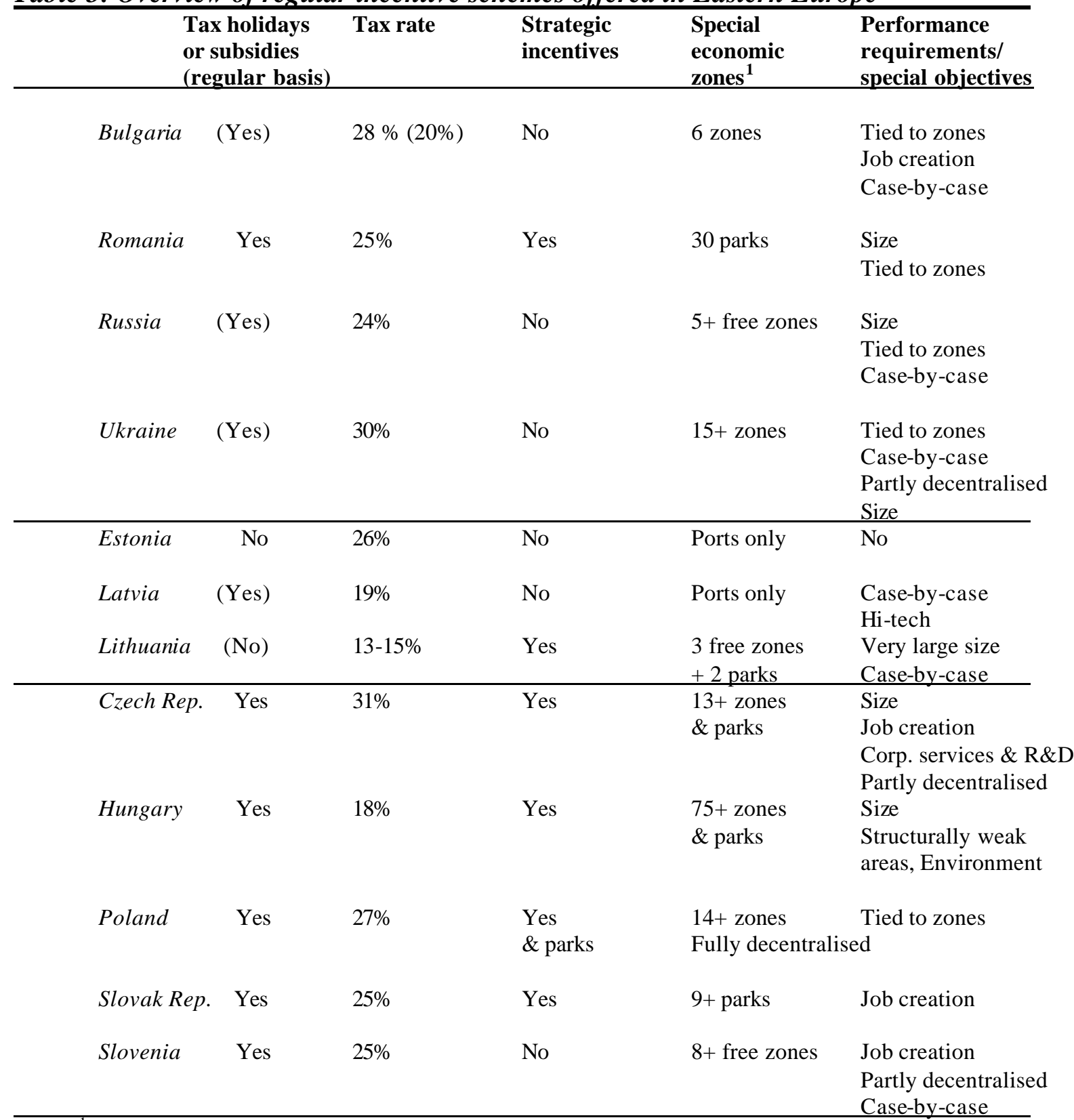

Notes: ${ }^{1}$ In 'free zones' (in short: zones) investors mainly benefits from lower taxes and trade duties. 'Industry parks' (in short: parks) have objectives beyond cost-cutting, such as trying to attract particular types of industry that match with already existing industries in the area or the skill-structure of the region.

Source: Dresdner Bank (2003): Investing in Central and Eastern Europe, Dresdner Bank AG, Group Economics, Frankfurt am Main, and the homepages of the national investment agencies in the Czech Republic (www.czechinvest.cz), Poland (www.paiz.gov.pl) and Russia (www.inves.ru $)$. 